\title{
WYDAWNICTWO BAUER - TRADYCYJNY WYDAWCA W CYFROWYM ŚWIECIE
}

Abstract

\section{BAUER PUBLISHER - TRADITIONAL PUBLISHER IN THE DIGITAL WORLD}

The Bauer publishing house has gained the position of the largest press publisher in Poland thanks to the creation of an extensive portfolio of magazines aimed at various groups of recipients. The publishing strategy based on a low copy price and efficient marketing ensured high sales revenues and relatively high independence from advertising revenues. Despite the decline in the readership of the printed press, the publishing house did not make any efforts to digitally transform its magazines and develop its activities on the Internet. Only in the face of the coronavirus pandemic, it created e-editions and websites of a few titles. However, the recent business decisions of the German owner indicate that instead of investing in digital change and waiting for its effects, it is more willing to quit the traditional media markets.

Keywords: magazine market, print publishers, effects of COVID-19

Artykuł ma na celu analizę sytuacji rynkowej Wydawnictwa Bauer, największego wydawcy czasopism w Polsce. Szczególną uwagę poświęcono ocenie ostatnich lat funkcjonowania spółki na zmieniającym się rynku wydawniczym oraz strategii na czas pandemii.

Funkcjonujące w Polsce od 1991 roku wydawnictwo było przedmiotem kilku opracowań medioznawczych, zwłaszcza poświęconych prasie kobiecej oraz udziałowi kapitału zagranicznego w polskich mediach (Sokół, 2004, 2005; Dąbrowska-Cendrowska, 2009, 2019). Jego inicjatywy prasowe oraz wyniki sprzedaży egzemplarzowej omawiano $\mathrm{w}$ specjalistycznych mediach ${ }^{1}$. W ostatnich latach

1 Zob. „Press”, „Media Polska”, „Media i Marketing Polska”, wirtualnemedia.pl. 
nie podejmowano jednak oceny strategii wydawniczej spółki, która - wbrew powszechnym w drugiej dekadzie XXI wieku trendom cyfryzacji i digitalizacji treści - pozostawała tradycyjnym wydawcą czasopism drukowanych.

Do analizy sytuacji rynkowej Wydawnictwa Bauer wykorzystano dane dotyczące produkcji (nakładu globalnego) oraz - pomijane do tej pory w badaniach medioznawczych - informacje o przychodach spółki, czyli wpływach ze sprzedaży egzemplarzowej czasopism i reklam w nich umieszczanych. Ocenę strategii wydawniczej oparto na wynikach finansowych spółki, a także na inicjatywach podejmowanych w obliczu malejącej sprzedaży egzemplarzowej oraz spadku przychodów. Analiza finansowa mieści się w zakresie badań stosowanych, właściwych dla rynkowej analizy mediów. Wzbogacono ją jednak o charakterystykę trendów występujących na rynku wydawców czasopism. Do dominujących trendów należy malejąca sprzedaż egzemplarzowa magazynów oraz spadające wpływy reklamowe w druku. Wydawcy czasopism rozpoczęli więc przenoszenie treści do internetu, szukając tam zasięgów i nowych możliwości zarabiania na reklamach. Podejmują też próby wprowadzenia subskrypcyjnych systemów płatnego dostępu do treści bądź zdywersyfikowanych źródeł przychodu, takich jak content commerce, usługi technologiczne czy e-commerce.

\section{Źródła sukcesu}

Wydawnictwo Bauer od początku istnienia na polskim rynku prasowym konsekwentnie rozbudowywało portfolio tytułów skierowanych do bardzo różnego odbiorcy: młodzieży, dzieci, kobiet, mężczyzn. Jak charakteryzowała je polska prasoznawczyni:

Magazyny te zdobyły w Polsce niespotykaną dotąd popularność: były nowością, bogato ilustrowane, kolorowe, tanie i nietrudne do kupienia, łatwe w czytaniu, reprezentowały typ masowego wydawnictwa $\mathrm{z}$ „dolnej półki”, dotąd w Polsce nieznanego. Na tle dotychczasowej polskiej produkcji „zgrzebnych” czasopism wydawanych na gazetowym papierze, z czarno-białymi, nieczytelnymi fotografiami, a przy tym trudnych do kupienia, gdyż nakłady nie zaspokajały potrzeb czytelniczych, wydawnictwa H. Bauera wabiły kolorową, błyszczącą okładką, ładnymi ilustracjami, lekką i przyjemną treścią, niskimi cenami (w porównaniu z polskimi), dobrze zorganizowaną promocją i reklamą (Sokół, 2004, s. 118).

Czasopisma Bauera, początkowo krytykowane za nieznajomość polskiego odbiorcy i oferowanie mu jedynie "kalek”, to znaczy tekstów zamieszczanych pierwotnie w niemieckich gazetach, szybko "nabrały "polskiego charakteru», dotyczyły spraw polskich, redagowane były przez zespół polski, stając się wydawnictwami jedynie na licencji niemieckiej” (Sokół, 2004, s. 121).

Oferta tytułów Wydawnictwa Bauer, tworzona początkowo wyłącznie na podstawie wskaźników demograficznych, wzbogacała się stopniowo o nowe typy czasopism 
odpowiadające zainteresowaniom i potrzebom czytelników: tv-guide’y, magazyny kulinarne, pisma parentingowe, motoryzacyjne, komputerowe i lifestyleowe dla kobiet. Przejmowano je głównie od innych wydawców, korzystając z ich już ugruntowanej pozycji czytelniczej.

Politykę wydawniczą cechowała ponadto duża pragmatyka. Pismo mogło funkcjonować tylko, gdy odnosiło sukcesy sprzedażowe i ekonomiczne. Ówczesny prezes wydawnictwa Witold Woźniak wprost deklarował, że nie przywiązuje się do tytułów i nie utrzymuje ich wbrew wynikom finansowym (Prewęcka, 1999, s. 24). Z rynku znikały więc nierentowne pisma, a na ich miejsce pojawiały się nowe, mogące zapewnić stabilne przychody ze sprzedaży egzemplarzowej. Taki potencjał wykazywały przede wszystkim tygodniki i dwutygodniki z programem telewizyjnym oraz zawierające treści rozrywkowe i poradnicze.

Wpływy ze sprzedaży czasopism stanowiły zdecydowaną większość przychodów wydawnictwa. Konkurenci utrzymywali wręcz, że down-market jest dominującym segmentem wydawniczym Bauera ${ }^{2}$. Wiele tytułów rzeczywiście osiągało pozycję lidera sprzedaży w swoich grupach, a konkurencja cenowa stanowiła skuteczną metodę rywalizacji o zdobycie jak najlepszej pozycji rynkowej.

Polityka niskich cen i coraz bardziej precyzyjna segmentacja oferty wydawniczej sprawiła, że Bauer stał się największym wydawcą magazynów w Polsce pod względem liczby tytułów, ich globalnego nakładu i sprzedaży egzemplarzowej. W pierwszej dekadzie XXI wieku sprzedaż ta przekraczała 300 milionów egzemplarzy rocznie.

Występujące okresowo problemy, takie jak recesja gospodarcza, spadek siły nabywczej społeczeństwa, kryzysy na rynku reklamy, coraz silniejsza konkurencja itp., Wydawnictwo Bauer pokonywało za pomocą sprawnego marketingu. Utrzymaniu nakładów służyły przede wszystkim dodatki specjalne, akcje promocyjne, konkursy i prezenty dla czytelników. Podobne praktyki stosowane przez innych wydawców wymuszały wprawdzie konieczność stopniowej redukcji kosztów, ale do 2010 roku wydawnictwo sukcesywnie zwiększało przychody ze sprzedaży.

Potwierdzeniem biznesowych sukcesów mogą być również inwestycje Grupy Bauer w inne segmenty rynku mediów w Polsce. W skład Grupy Bauer Media, oprócz wydawnictwa prasowego, wchodziła początkowo tylko księgarnia wysyłkowa. W latach 2006-2008 koncern kupił za 450 mln zł jeden z czterech największych portali internetowych - Interię.pl i lidera rynku radiowego - Grupę RMF. Zbudował też drugą drukarnię, obsługującą wydawnictwa Bauera w Polsce i w Europie. Według rankingu „Rzeczpospolitej” przychody ze sprzedaży Grupy Bauer Media wzrosły z 446 mln zł w 2002 roku do 1,72 mld zł w roku 2010 (Lista 500 „Rzeczpospolitej”).

2 Tak określano segment pism skierowanych do masowego - i niezbyt wymagającego - odbiorcy, w niskiej cenie egzemplarzowej, opierających się na wpływach sprzedażowych, niezależnych od reklamy. Por. wypowiedź Ewy Redel-Bydłowskiej, wiceprezes Edipresse Polska dla magazynu „Press”, https://www.press.pl/tresc/37369, bauer-wprowadza-wysokonakladowy-tygodnik-dla-religijnychkobiet (dostęp: 10.09.2020). 


\section{Internetowa bezradność}

Samo wydawnictwo $\mathrm{w}$ niewielkim stopniu korzystało $\mathrm{z}$ możliwości multimedialnej współpracy z radiem i internetem przy tworzeniu treści redakcyjnych i oferty reklamowej. Na Interia.pl powstały wprawdzie powiązane z tytułami prasowymi serwisy, np. Swiatseriali.pl, Styl.pl czy Cdaction.pl, ale oznaczało to raczej oddanie w ręce portalu zarządzanie kontentem niż budowanie społeczności internetowej wokół marki wydawcy czasopism. Bauer nie wierzył, że autonomiczne serwisy poszczególnych tytułów będą w stanie konkurować z portalami horyzontalnymi i mediami społecznościowymi. Obawiał się również, że treści udostępniane w internecie będą prowadzić do swoistej „kanibalizacji” czytelnictwa wydań drukowanych. Przez lata zaniedbywał więc nie tylko marketing treści, czyli rozpowszechnianie ich na wielu platformach w celu zbudowania ścisłych relacji z czytelnikami, ale przede wszystkim stracił szansę na poznanie czytelników online. Brak własnych stron internetowych uniemożliwiał śledzenie ich zainteresowań, czasu spędzonego na stronie, liczby przeczytanych artykułów itp. Bez tej wiedzy trudno zbudować system płatnej dystrybucji treści, zwłaszcza jeśli przegapiło się moment smartfonowej rewolucji i fakt, że większość internautów konsumuje media na swoich telefonach. Wydawnictwo Bauer wprowadziło do sprzedaży e-wydania swoich tytułów dopiero w 2020 roku, w obliczu pandemii koronawirusa. Do tego czasu nie pokusiło się o stworzenie aplikacji na smartfony nawet dla najbardziej popularnych czasopism. W swoim sklepie internetowym oferowało wyłącznie sprzedaż i prenumeratę wydań drukowanych.

Przywiązanie do tradycyjnego modelu wydawniczego doceniano w branżowych rankingach, przyznając Bauerowi wielokrotnie tytuł Wydawcy Roku za „wierność strategii”, czyli rozwijanie tytułów z tradycyjnego portfolio, zmniejszanie lub zwiększanie ich cykliczności, wprowadzanie nowych pism i ich wydań specjalnych, odpowiedź na zmieniające się potrzeby odbiorców ${ }^{3}$. To podążanie za czytelnikiem, dostosowanie do jego wymagań najlepiej ilustruje dojrzewająca wraz z wiekiem odbiorców oferta tytułów. Najpierw zaczęły z niej znikać pisma dla dzieci i młodzieży. Spadek czytelnictwa takich pism, jak „Filipinka”, „Bravo Girl”, „Fun Club” i „Twist” czy „Bravo”, wyraźnie wskazywał, że ich czytelnicy przenieśli się do internetu, zwłaszcza do serwisów społecznościowych. Zamiast podążać za nimi, Bauer zaczął w 2015 roku wydawać „TubeNews” (czasopismo o gwiazdach YouTube’a i mediów społecznościowych), a następnie zamknął związany z drukowanym magazynem serwis Bravo.pl. Wkrótce z rynku zniknęły wszystkie drukowane na papierze tytuły dla młodzieży. Podobny los spotkał młodych rodziców. Pismo „Mam Dziecko”, które rozwijało się dynamicznie na fali popularności magazynów parentingowych, zostało zlikwidowane w 2016 roku. Treści, dotąd ukazujące się w drukowanym tytule,

3 Por. np. uzasadnienia wyróżnień przyznawanych wydawnictwu Bauer przez magazyn „Media \& Marketing Polska” w raportach „Wydawcy” z 2015 i 2018 r. 
przeniesiono do serwisu Mamdziecko.interia.pl., nie podejmując się stworzenia autonomicznej strony internetowej lub elektronicznej wersji czasopisma.

Wydawnictwo skupiło się na znacznie starszych wiekowo grupach odbiorców. Zwłaszcza kobietach wyznających bardziej tradycyjne wartości, w tym rodzinne i religijne, oraz „praktyczne” podejście do życia. Grupą docelową Bauera stały się kobiety powyżej 50. roku życia, mieszkanki mniejszych miejscowości, z wykształceniem podstawowym lub średnim, które preferowały tradycyjne media i nie migrowały masowo do internetu. To dla nich tworzono pisma zajmujące się w coraz większym stopniu tematyką zdrowotną (niż modą i urodą), kulinariami, ogrodem, prowadzeniem domu, opieką nad wnukami i seniorami. Nawet treści czysto rozrywkowe ewoluowały w kierunku „nostalgicznych wspomnień”, ikon kina i estrady XX wieku, „życiowych” historii, poruszających doświadczeń „zwykłych ludzi”. Pojawiły się też pisma ezoteryczne, traktujące o duchach, zjawiskach nadprzyrodzonych i magii, a obok nich pisma „religijne”, o których wydawca pisał między innymi, że są „skierowane do czytelnika zaangażowanego w życie Kościoła katolickiego”.

Tworzeniu portfolio dla dojrzałych kobiet towarzyszyły zmiany czysto techniczne: wprowadzanie prostszych layoutów i większej czcionki oraz stosowanie w rozliczeniach z reklamodawcami poszerzonej grupy komercyjnej (16-59 lat).

Choć czytelniczki tzw. prasy kobiecej, zwłaszcza starsze i najmniej cyfrowo mobilne panie $\mathrm{z}$ mniejszych miejscowości, wykazywały największe przywiązanie do tradycyjnej prasy drukowanej ${ }^{5}$, tytuły Bauera sukcesywnie notowały spadki nakładów i sprzedaży egzemplarzowej. W 2013 roku nakład wszystkich czasopism tego wydawcy wyniósł 389 mln egzemplarzy. W 2019 roku, mimo zakupu dodatkowych tytułów z segmentu poradników ${ }^{6}$, nakład globalny spadł do $317 \mathrm{mln}$, czyli o $70 \mathrm{mln}$ egzemplarzy. W tym czasie liczba użytkowników serwisów kobiecych w polskim internecie rosła, podobnie jak aktywność w sieci starszych wiekowo grup internautów. Z badań nad zachowaniem różnych grup wiekowych w internecie wynikało, że najbardziej aktywni w sieci są użytkownicy w wieku 40-49 lat. Stanowili oni w 2019 roku 18,5\% wszystkich internautów, generując także najwięcej odsłon (19,8\%) oraz spędzając online najwięcej czasu (20,2\%). Co dziesiąty internauta miał 60 i więcej

4 Por. charakterystyki poszczególnych tytułów na stronie Bauer.pl.

5 Według „Diagnozy społecznych zachowań czytelniczych w obrębie prasy papierowej i cyfrowej” czasopisma kobiece miały w 2013 r. najwyższy poziom czytelnictwa wśród prasy drukowanej (56,6\% respondentów czytało je w wersji papierowej), ale i najniższy potencjał wzrostu czytelnictwa (61\% respondentów zamierzało je czytać w najbliższych latach, w niewielkim stopniu korzystając $\mathrm{z}$ ich cyfrowych wersji). Niski potencjał wzrostu cyfrowej prasy kobiecej wynikał m.in. z mniejszej otwartości na nowe technologicznie sposoby konsumpcji treści wśród jej czytelniczek oraz z niewielkiej liczby tytułów prasy kobiecej dostępnych w wersji cyfrowej. Zob. Diagnoza społecznych zachowań czytelniczych $w$ obrębie prasy papierowej i cyfrowej. Nowe platformy dostępu do treści. Transformacja prasy, http://www.pik.org.pl/upload/files/Raport\%20RYNEK\%2011-02-2014\%20(R)\%20word\%20 IWP-2.pdf (dostęp: 14.09.2020).

6 W czerwcu 2019 r. Wydawnictwo Bauer przejęło od Edipresse Polska dwutygodniki „Przyjaciółka” i „Pani Domu” oraz miesięcznik „Poradnik Domowy”. 
lat, wykonywał co dziesiątą odsłonę i przypadało na niego 10,7\% czasu spędzanego $\mathrm{w}$ internecie (Gemius, 2019). Wynikało z tego, że nawet najstarsi wiekiem odbiorcy mediów korzystają z internetu, a grupa docelowa czasopism Wydawnictwa Bauer będzie za kilka lat „cyfrowymi tubylcami”, a nie wykluczonymi technologicznie konsumentami wyłącznie drukowanej prasy.

\section{Malejące przychody, stabilne zyski}

Uzasadnienia dla strategii wydawniczej Bauera można szukać w rentowności, którą udawało się przez lata osiągać w druku. Mimo spadających przychodów ze sprzedaży egzemplarzowej i reklam wydawnictwo miało stabilne zyski przekraczające $100 \mathrm{mln}$ zł rocznie. Przyczyniała się do tego sukcesywna redukcja kosztów (zob. wykres 1). Uwagę zwraca szczególna dyscyplina budżetowa, jeśli chodzi o wynagrodzenia i zatrudnienie. Na etatach w spółce pracowało na ogół niespełna 600 osób, z czego najwyżej 50\% stanowili dziennikarze. Produkcją treści dla kilkudziesięciu tytułów zajmowali się więc głównie, znacznie tańsi w utrzymaniu, nieetatowi współpracownicy i freelancerzy.

Wykres 1. Wyniki finansowe wydawnictwa Bauer w latach 2013-2018 (w mln zł)

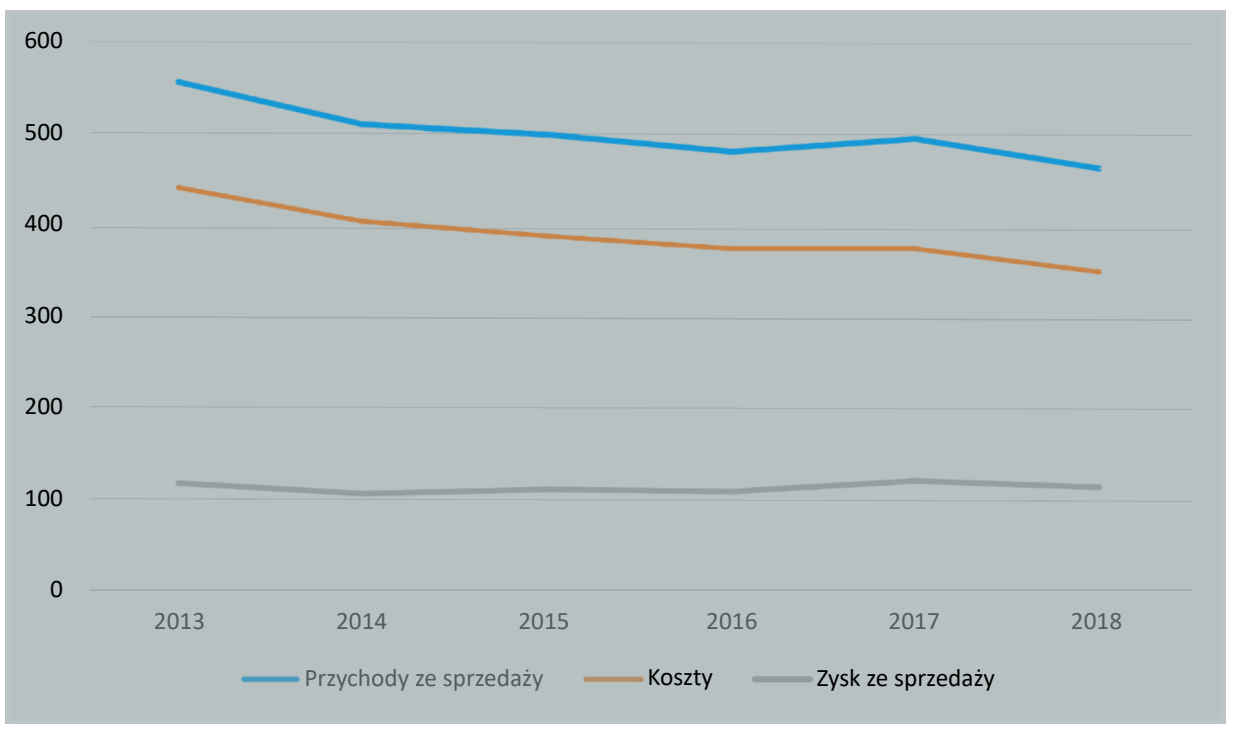

Źródło: KRS, Sprawozdania finansowe wydawnictwa Bauer. 
Skala działalności i wielkość przychodów w druku mogła w pełni usprawiedliwiać ambiwalentny stosunek wydawcy do przychodów cyfrowych. Należący do Bauer Media Group portal internetowy Interia.pl notował przez lata przychody ze sprzedaży niższe od zysku ze sprzedaży, jaki osiągało wydawnictwo ${ }^{7}$. Zyski ze sprzedaży produktów digitalowych (głównie reklamy) Grupy Interia.pl wynosiły niespełna $1 / 5$ zysków ze sprzedaży egzemplarzy i reklam w druku wydawnictwa Bauer. Chociaż portal mógł się poszczycić grupą ponad 18 mln użytkowników miesięcznie jego rentowność sprzedaży wyniosła w 2018 roku 17,1\%, a w 2019 roku $17,7 \%^{8}$. Wskaźnik rentowności sprzedaży wydawnictwa w 2018 roku przekroczył 24\%. Sprzedaż czasopism Bauera można w tym czasie szacować również na $18 \mathrm{mln}$ egzemplarzy miesięcznie. Oznacza to, że reklama cyfrowa nie przynosi wydawcom takich zysków, jak sprzedaż egzemplarzowa i reklama w druku.

Ta konstatacja, podobnie jak zestawienie wyników finansowych wydawnictwa i wybranego portalu internetowego, nie charakteryzuje oczywiście w pełni sytuacji spółki na rynku mediów. Tę odzwierciedla przede wszystkim strukturalny spadek czytelnictwa oraz wydatków reklamowych w prasie drukowanej.

Z danych Związku Kontroli Dystrybucji Prasy (ZKDP) wynika, że sprzedaż tytułów kontrolowanych przez związek w latach 2014-2019 spadła o 37\%, z 709,7 $\mathrm{mln}$ do $447,5 \mathrm{mln}$ egzemplarzy ${ }^{9}$. W tym samym czasie wydatki reklamowe w czasopismach zmalały o $35 \%$ z $441 \mathrm{mln}$ zł do $285 \mathrm{mln} \mathrm{z}^{10}$. Chociaż Wydawnictwo Bauer nie podaje, jaką część przychodów czerpie ze sprzedaży egzemplarzowej, a jaką z reklamy, osiągało lepsze wyniki niż rynek. W okresie 2013-2019 odnotowało ono spadek przychodów na poziomie $25 \%$. Nie oznacza to, że zarząd spółki nie dostrzegał zagrożeń, zwłaszcza że w dłuższej perspektywie czasowej spadki wpływów reklamowych rysowały się jeszcze bardziej dramatycznie. Od 2008 roku inwestycje reklamowe w magazynach spadły trzykrotnie. Już w 2014 roku Witold Woźniak, ówczesny prezes Grupy Bauer Media, alarmował:

Jeśli wydatki na reklamę w magazynach będą wciąż malały w tym samym tempie przez najbliższe trzy lata, to przychody segmentu zmniejszą się o kolejne 40 proc. (...) Wydawcy zaczną zamykać nierentowne tytuły, w końcu będą likwidowane całe wydawnictwa. I to jest scenariusz na dwa, trzy lata. Nie więcej. Już większość wydawnictw jest na granicy progu rentowności. Są trzy, cztery wydawnictwa, które zarabiają, a pozostałe podejmują radykalne kroki dla ratowania wyników finansowych. Jednak te oszczędności są dużo mniejsze niż aktualne spadki przychodów reklamowych (Dziwisińska, 2014).

Jego przewidywania zaczęły się sprawdzać pod koniec 2019 roku, kiedy z rynku czasopism wycofał się Marquard Media Polska, zamykając wszystkie swoje

7 Przechody ze sprzedaży Grupy Interia.pl dopiero w 2018 i 2019 r. przewyższyły zyski wydawnictwa Bauer, bo wyniosły odpowiednio: 114,3 i 115,7 mln zł.

8 Wskaźnik rentowności sprzedaży to stosunek zysku netto do przychodów netto ze sprzedaży.

9 Por. IWP, Rynek prasy, https://iwp.pl/rynek-wydawcow/ (dostęp: 10.09.2020).

10 Por. raporty Publicis Groupe (wcześniej Starcom) publikowane m.in. przez Wirtualnemedia.pl. 
drukowane tytuły. Katastrofalny scenariusz zrealizował się natomiast w 2020 roku, gdy na skutek pandemii koronawirusa załamał się nie tylko rynek reklamy, ale i sprzedaż egzemplarzowa prasy drukowanej.

\section{Próby zmiany strategii}

Zanim COVID-19 boleśnie dotknął rynek wydawców prasy, niemiecki koncern Bauer Media Group podjął próbę dalszej dywersyfikacji swojej działalności w Polsce. W 2015 roku złożył ofertę kupna TVN, co sugerowało chęć poszerzenia wpływów na rynku prasy, radia i internetu o telewizję ${ }^{11}$. Większościowy pakiet akcji TVN nabyli ostatecznie Amerykanie, a Bauer zadowolił się inwestycjami w produkty ubezpieczeniowe i finansowe (kupno Rankomat.pl i eBroker) oraz marketing $\mathrm{w}$ internecie (przejęcie firm zajmujących się pozycjonowaniem). Nie były to tak spektakularne inwestycje, jak zakup porównywarki cenowej Skąpiec.pl przez Onet lub agregatorów ofert z e-sklepów (Domodi.pl i Homebook.pl) przez Wirtualną Polskę, ale wzmacniały Interię i świadczyły, że koncern dostrzega rosnący potencjał reklamy cyfrowej i e-commerce. Internetowe akwizycje nie okazały się najwyraźniej sukcesem, bo w lipcu 2020 roku cały portal został sprzedany Telewizji Polsat.

Mariaż z internetem Wydawnictwa Bauer wymuszały oczekiwania reklamodawców chcących dotrzeć ze swoją ofertą do młodych klientów. Miała temu służyć uruchomiona w 2018 roku platforma Influence Me pośrednicząca w nawiązywaniu współpracy reklamowej z influencerami prowadzącymi blogi lub kanały na YouTubie. Jak przyznała dyrektor Biura Reklamy Wydawnictwa Bauer w Polsce: „Influence Me to nasza odpowiedź na zmianę strategii marketingowych naszych klientów, poszukujących kontentowych ofert digitalowych, uzupełniających ich obecność w prasie"12. O kompetencjach Wydawnictwa Bauer w łączeniu świata online i prasy drukowanej nie najlepiej jednak świadczy fakt, że Durszlak.pl - drugi, obok Influence Me, projekt internetowy - zakończył działalność z końcem sierpnia 2020 roku. Popularny agregator przepisów kulinarnych znalazł się w zasobach wydawnictwa, gdy przejęło ono całość udziałów w Phoenix Press i funkcjonował tam niespełna cztery lata.

Jeszcze gorzej Wydawnictwo Bauer radziło sobie z wykorzystywaniem internetu jako platformy do dystrybucji treści. Jak już wspomniano, strony internetowe i e-wydania wybranych czasopism zaczęto tworzyć dopiero po wybuchu pandemii koronawirusa, gdy nastąpił niespotykany dotąd wzrost zapotrzebowania na usługi cyfrowe,

11 Poinformował o tym serwis biznesowy „Gazety Wyborczej”, a w ślad za nim inne media i serwisy agencyjne.

12 jd, Bauer tworzy platformę Influence Me do wspótpracy z twórcami internetowymi, https:// www.wirtualnemedia.pl/artykul/bauer-influence-me-izabela-sarnecka-wspolpraca-z-influencerami (dostęp: 14.09.2020). 
a wydawnictwo straciło serwisy na portalu Interia.pl. Zasięg marki w sieci trzeba jednak budować latami, więc cyfrowe debiuty nie były imponujące. Z danych ZKDP wynika, że sprzedaż e-wydań „Twojego Stylu” w czerwcu wyniosła 753 egzemplarze, w lipcu - 447, a sierpniu już tylko 349. Sprzedaż wydań drukowanych w tym czasie była na poziomie 120 tysięcy egzemplarzy miesięcznie. E-wydania miesięcznika „Pani” znalazły w czerwcu 14 nabywców, w lipcu - 18, a w sierpniu - 24. Średnia miesięczna sprzedaż wydań drukowanych oscylowała wokół 45 tys. egzemplarzy.

COVID-19 uderzył w rynek wydawców prasy w dwojaki sposób. Spadła sprzedaż wydań drukowanych, bo w połowie marca 2020 roku Polacy otrzymali zalecenia pozostania w domach, zdalnej pracy i nauki. Wiele punktów sprzedaży prasy przestało działać na skutek ograniczeń w funkcjonowaniu transportu i handlu. Lockdown zmniejszył popyt na wiele produktów, więc reklamodawcy ograniczyli wydatki lub dokonali relokacji budżetów marketingowych z mediów tradycyjnych do internetowych. Z danych ZKDP na temat sprzedaży kontrolowanych przez związek tytułów wynikało, że rozpowszechnianie płatne czasopism zmniejszało się, w ponadnormatywny sposób, od marca do maja (zob. tabela 1). W stosunku do tego samego okresu ubiegłego roku największy spadek zanotowano w kwietniu (około 19\%) i w maju (około 17\%).

Tabela 1. Rozpowszechnianie płatne czasopism w I półroczu 2020 i 2019 roku

\begin{tabular}{|l|l|l|l|}
\hline & \multicolumn{1}{|c|}{2020} & \multicolumn{1}{|c|}{2019} & \multicolumn{1}{|c|}{ Zmiana 2020 do 2019 } \\
\hline Styczeń & 22927158 & 24870739 & $-8 \%$ \\
\hline Luty & 21105698 & 23225155 & $-9 \%$ \\
\hline Marzec & 21968778 & 23137096 & $-5 \%$ \\
\hline Kwiecień & 20561588 & 25271263 & $-19 \%$ \\
\hline Maj & 18967606 & 22886572 & $-17 \%$ \\
\hline Czerwiec & 20104572 & 20973624 & $-4 \%$ \\
\hline
\end{tabular}

Źródło: ZKDP, Wyniki sprzedaży czasopism płatnych.

Wpływy reklamowe wydawców czasopism w tym czasie zmniejszyły się w porównaniu z pierwszym półroczem 2019 roku o 35,3\%. Z szacunków Publicis Groupe wynika, że na reklamę w magazynach wydano o $50 \mathrm{mln}$ zł mniej. Największe cięcia w budżetach reklamowych poczyniły firmy z sektora higiena i pielęgnacja (w magazynach wydały o 46,4\% mniej) oraz odzież i dodatki (o $44,7 \%$ mniej). Cały rynek reklamy zmniejszył się w pierwszym półroczu o 15,3\%, więc czasopisma - obok kina i reklamy zewnętrznej - ucierpiały na pandemii koronawirusa najbardziej (Publicis Groupe, 2020). 
Wydawcy prasy zareagowali na te zmiany bardzo gwałtownie. Wielu zlikwidowało lub zawiesiło wydawanie najmniej rentownych tytułów, ograniczyło zatrudnienie i pensje pracowników. Wydawnictwo Bauer postąpiło podobnie. W kwietniu 2020 roku zamknęło siedem tytułów z segmentów poradniczo-rozrywkowego i true stories oraz 27 wydań specjalnych. Spółka pożegnała się z 27 osobami, wypowiedzenia dostały też zespoły „CD-Action” i „PC Format”. W maju nastąpiła dalsza redukcja zatrudnienia (o 20 osób). W tym czasie podjęto próby ograniczenia spadków sprzedaży. Czytelnikom zaproponowano prenumeratę większej liczby tytułów drukowanych z dostawą do domu. Nakłady z zamkniętych galerii handlowych, czy chociażby zmniejszającego liczbę swoich punktów sprzedaży Empiku, przekierowano do sklepów spożywczych. E-wydania kilku czasopism wprowadzono do oferty e-kiosków.

Wydawnictwo starało się też przekonać reklamodawców, że prasa drukowana $\mathrm{w}$ czasach pandemii ma się dobrze, więc nie powinni oni rezygnować $\mathrm{z}$ umieszczania w niej reklam. W kwietniu 2020 roku przygotowano raport „Zmiana zachowań w świecie pełnym wyzwań. Jak zmienia się życie w obliczu pandemii i jakie ma to przełożenie na czytanie prasy", w którym przedstawiono między innymi takie oto wnioski: „Prasa kolorowa wspiera czytelników bo dostarcza rozrywki, pomaga oderwać się od trudnej rzeczywistości, pomaga przetrwać okres zamknięcia w domu”; „Użytkowanie mediów stało się bardziej intensywne, ze względu na fakt, że ludzie spędzają więcej czasu w domu" (Raport Wydawnictwa Bauer, 2020). Zaprezentowano też wyniki mało reprezentatywnego badania na grupie 53 czytelniczek magazynów w wieku 18-34 lat, z których 13\% zadeklarowało, że oddaje się lekturze czasopism częściej niż przed pandemią. Mogło to niestety sugerować, że $87 \%$ badanych robi to rzadziej, albo - w najlepszym razie - nie zmieniło swoich zachowań czytelniczych.

Chociaż załamanie rynku reklamowego nie pozostanie bez wpływu na przychody wydawców w 2020 roku, z perspektywy Wydawnictwa Bauer najważniejsze stało się zniwelowanie strat na rynku czytelniczym. Spółka podjęła próbę zwiększenia liczby prenumerat pocztowych swoich magazynów, ale - co widać chociażby na przykładzie takich pism, jak „Twój Styl” czy „Pani” - nie osiągnęła oczekiwanych rezultatów. Dane na ten temat są zawarte w tabeli 2.

Nie mogąc zahamować spadków sprzedaży egzemplarzowej, Bauer zaczął odbudowywać zmniejszone portfolio. W czerwcu wprowadził na rynek trzy nowe magazyny rozrywkowe z krzyżówkami i szaradami, w lipcu przejął bezpłatny „Magazyn 60+", dystrybuowany w sieci aptek, a w sierpniu rozpoczął wydawanie magazynu dla osób, które wyprowadziły się z miasta na wieś. Jego pozycja na rynku czasopism drukowanych, jak się wydawało, nie była zagrożona, tym bardziej że konkurencja w tym segmencie zdecydowanie słabła.

Edipresse Polska już w 2019 roku, sprzedając Bauerowi trzy tytuły poradnikowe („Przyjaciółkę”, „Panią Domu” oraz „Poradnik Domowy”), informowało, że skupiać się będzie na rozwoju marek digitalowych. Pod pretekstem COVID-19 nie 
zmniejszyło liczby wydawanych w druku tytułów, ale wzmogło promocję e-wydań swoich magazynów dostępnych w tej formie od lat.

Tabela 2. Rozpowszechnianie płatne wybranych czasopism Wydawnictwa Bauer w pierwszym półroczu 2020 roku

\begin{tabular}{|l|l|l|l|l|l|l|}
\hline \multirow{2}{*}{} & \multicolumn{2}{|c|}{ „Twój Styl” } & \multicolumn{2}{c|}{ „Pani” } & \multicolumn{2}{c|}{ "Tele Tydzień” } \\
\cline { 2 - 7 } & $\begin{array}{l}\text { Sprzedaż } \\
\text { wydań } \\
\text { drukowa- } \\
\text { nych }\end{array}$ & $\begin{array}{l}\text { Prenume- } \\
\text { rata wydań } \\
\text { drukowa- } \\
\text { nych }\end{array}$ & $\begin{array}{l}\text { Sprzedaż } \\
\text { wydań dru- } \\
\text { kowanych }\end{array}$ & $\begin{array}{l}\text { Prenume- } \\
\text { rata wydań } \\
\text { drukowa- } \\
\text { nych }\end{array}$ & $\begin{array}{l}\text { Sprzedaż } \\
\text { wydań dru- } \\
\text { kowanych }\end{array}$ & $\begin{array}{l}\text { Prenume- } \\
\text { rata wydań } \\
\text { drukowa- } \\
\text { nych }\end{array}$ \\
\hline I & 130323 & 7377 & 49020 & 3105 & 638352 & - \\
\hline II & 130475 & 7231 & 48575 & 3084 & 635784 & - \\
\hline III & 132132 & 7100 & 48010 & 3051 & 632798 & - \\
\hline IV & 129668 & 7019 & 47412 & 3021 & 629506 & - \\
\hline V & 128943 & 7027 & 47358 & 2993 & 623474 & 1 \\
\hline VI & 122052 & 7058 & 46329 & 2965 & 618431 & 20 \\
\hline
\end{tabular}

Źródło: dane ZKDP.

Agora, która odejście od rozwoju papierowej wersji czasopism ogłosiła w 2017 roku, zamykając kilka tytułów, kontynuowała tę strategię wydawniczą w czasach pandemii. W kwietniu podjęto decyzję o zakończeniu wydawania miesięczników „Avanti” i „Logo”. Spółka zamierzała jednak rozwijać ich serwisy internetowe, mając nadzieję na powodzenie formuły content-to-commerce.

Zarząd Burda Polska, przejmując w 2013 roku wydawnictwo Gruner+Jahr w Polsce, zapewniał, że wierzy w prasę drukowaną i zamierza umacniać swoją pozycję w segmencie magazynów luksusowych i lifestyleowych. W kolejnych latach nie wypracował jednak jasnej strategii działania. Z jednej strony wprowadzał na rynek nowe tytuły drukowane o charakterze poradnikowym i rozrywkowym („Kocham Szycie” w 2018 r., „Zdrowie na Talerzu”, „Mistrzowie Smaku”, „Focus Śledczy”, „Zdrowie i Życie” w 2019 r.), z drugiej inwestował w serwisy internetowe swoich tytułów i cyfrowe kanały dotarcia do czytelników. W związku z pandemią nie zamknięto żadnych tytułów, ale zwolnienia dotknęly przede wszystkim działy redakcyjne, edytorskie i reklamowe wydawnictw drukowanych, więc - wbrew temu, co jeszcze w końcu 2019 roku deklarował prezes Burda Media Polska Alexander Sorg (Niewiadomska, 2019) - rozwój digitalu odbywał się kosztem pism papierowych.

Grupa ZPR Media w kwietniu 2020 roku zakończyła wydawanie miesięczników „Podróże” i „Żagle”, a w maju tego roku miesięcznika „Zdrowie”. W komunikatach prasowych stwierdzono wprost, że segment podróżniczo-turystyczny, jako 
najbardziej dotknięty skutkami pandemicznych ograniczeń, długo jeszcze nie będzie przynosił wydawcom zysków. Przyznano też, że koronawirus tylko zintensyfikował i utrwalił zachowania odbiorców mediów szukających wszelkiego rodzaju informacji i porad $\mathrm{w}$ internecie ${ }^{13}$. To przyspieszyło decyzje o ograniczaniu działalności w druku i dalsze inwestycje w produkty cyfrowe.

\section{Kilka cyfr w ramach podsumowania}

Wydawnictwo Bauer, istniejące na polskim rynku już 30 lat, stało się w tym czasie największym wydawcą prasy. Jego roczna produkcja czasopism przekracza $300 \mathrm{mln}$ egzemplarzy, a sprzedaż szacuje się na około $200 \mathrm{mln}$ egzemplarzy rocznie. Pozostaje też najbardziej tradycyjnym wydawcą, uznając działalność w druku za podstawową bez względu na poczynania konkurencji oraz rynkowe trendy. Autonomiczne serwisy internetowe swoich tytułów czy ich e-wydania zaczął tworzyć dopiero w 2020 roku. Niezmienna pozostaje też strategia spółki polegająca na produkcji czasopism skierowanych do zróżnicowanych grup odbiorców, w niskiej cenie egzemplarzowej, bazujących na wpływach sprzedażowych, w dużej mierze niezależnych od reklamy.

Model, w którym odbiorcy stanowią główne źródło finansowania treści, jest dziś uznawany za najbardziej pożądany w nowych mediach i przybiera tam formę subskrypcji czy finansowania społecznościowego. W mediach tradycyjnych, między innymi w prasie, ustępował modelowi reklamowemu, który zapewniał wyższą rentowność produkcji. Dla egzemplifikacji tej tezy wystarczy podać, że produkcja miliona egzemplarzy statystycznego tytułu Bauera daje mu od lat przychód w wysokości około 1,4 mln zł. Przychód z produkcji miliona egzemplarzy czasopisma $\mathrm{u}$ innych wydawców jest kilkakrotnie wyższy. Mniejsze przychody z produkcji nie oznaczają jednak niższych zysków, bo koszty, jakie Bauer ponosi przy produkcji miliona egzemplarzy statystycznego pisma są również od lat niezmienne i wynoszą około 1,1 mln zł. Konkurenci Bauera, którzy w ostatnich latach notują straty ze sprzedaży, wydają przy produkcji jednego miliona egzemplarzy kilkakrotnie więcej. Na te zwiększone koszty składają się między innymi środki wydawane na cyfrową produkcję i dystrybucję treści. Nie przynoszą one szybkich korzyści w postaci opłat czytelników i znacznych wpływów z reklamy w internecie, ale są inwestycją w przyszłość.

Kierując się krótkoterminową racjonalnością ekonomiczną, Wydawnictwo Bauer nie inwestuje znaczących sił i środków w cyfryzację swoich tytułów. Nie tworzy tym samym szansy na pozyskanie młodych czytelników ani alternatywy dla -

13 Por. Tw, Grupa ZPR Media rezygnuje z miesięcznika „Zdrowie” i zwalnia pracowników, https://www.wirtualnemedia.pl/artykul/koniec-miesiecznika-zdrowie-wlasciel-zpr-media-zwalniapracownikow (dostęp: 14.09.2020). 
coraz bardziej cyfrowych - dojrzałych odbiorców. Szczególnie niepokojące jest to, że czołowy wydawca pism poradnikowych i rozrywkowych dla kobiet nie dostrzega zmian w sposobie docierania do tego typu treści u swoich czytelniczek. Tymczasem internetowe serwisy z kategorii styl życia, do których zalicza się zarówno ogólne serwisy kobiece, jak i te poświęcone między innymi zdrowiu, kuchni i gotowaniu, modzie i urodzie, mają rosnący zasięg. W październiku 2016 roku aż 81\% wszystkich internautów odwiedziło co najmniej jeden serwis z kategorii „Styl życia” (PBI, 2016). Wśród najpopularniejszych są serwisy należące do innych wydawców prasy (Ringier Axel Springer Polska; Edipresse Polska; Agora; ZPR Media), w tym bezpośrednio powiązane z tytułami prasowymi, na przykład Party.pl oraz Viva.pl. (Edipresse Polska) czy Wysokieobcasy.pl (Agora). Wprawdzie monetyzacją treści zawartych w magazynach, czyli sprzedażą e-wydań swoich tytułów mogła się w 2019 roku poszczycić jedynie Grupa ZPR Media ${ }^{14}$, ale tak zwaną inną płatną dystrybucję e-wydań prowadzili też pozostali wydawcy. Zachowawczą politykę Bauera wobec projektów online zauważył nawet branżowy miesięcznik, przyznając mu dotychczas tytuły „Wydawcy Roku”. W raporcie za 2019 rok Wydawnictwo Bauer okrzyknięto „Rozczarowaniem Roku” (Wydawcy, 2019).

Zwiększanie zasięgu tytułów na komputery i telefony komórkowe stało się koniecznością na długo przed wybuchem pandemii. Przyczynił się do tego przede wszystkim rozwój mediów społecznościowych. Jako miejsce społecznej produkcji treści media społecznościowe stały się konkurencją dla produkcji medialnej, ale jako kanał dystrybucji treści zaczęły wspierać wydawców w interakcjach z czytelnikami. Bez silnej obecności w internecie nie będzie możliwości zniwelowania spadku czytelnictwa treści prasowych w druku. Kolejne wydania Digital News Report wskazują, ze rośnie liczba osób uzyskujących dostęp do informacji za pośrednictwem mediów społecznościowych i aplikacji agregujących wiadomości (Reuters Institute, 2019). Dla wielu wydawców obecność na tych platformach jest już codziennością, choć nie uporali się oni jeszcze z problemem atrybucji treści ${ }^{15}$, a tym samym zarabiania na nich.

Chociaż preferowany przez Wydawnictwo Bauer model biznesowy zapewnia mu na razie stabilne zyski z działalności wydawniczej, nie wydaje się perspektywiczny w przypadku dalszego spadku czytelnictwa egzemplarzy drukowanych. Świadczy o tym radykalne ograniczenie liczby wydawanych tytułów w sytuacji lockdownu, ale też, podjęte pospiesznie, próby odbudowania portfolio, w nadziei odzyskania wpływów ze sprzedaży egzemplarzowej. Strukturalny, a nie tylko wywołany pandemią, spadek sprzedaży czasopism w druku prędzej czy później zagrozi przychodom wydawnictwa. Tym bardziej że trendy spadkowe w wydatkach reklamowych na prasę drukowaną od lat są niezmienne. Otwarte pozostaje więc pytanie: Jak długo, dzięki redukcji kosztów, wydawnictwu uda się utrzymać dodatni

14 Por. dane ZKDP.

15 Pod tym pojęciem rozumie się powiązanie treści ze źródłem (wydawcą lub autorem), z którego pochodzi. 
wynik finansowy? Odpowiedź na pytanie, co będzie, gdy pojawią się straty, przynoszą decyzje o zakończeniu działalności podjęte przez Bauer Media Group w kilku krajach. Niesatysfakcjonujące wyniki finansowe były przyczyną wycofania się z rynku czeskiego i słowackiego w 2018 roku. Kryzys reklamowy i sprzedażowy wywołany pandemią spowodował ucieczkę z Nowej Zelandii, Rumunii oraz, w znacznej mierze, z Australii. Nawet ogromny rosyjski rynek prasy, na którym Bauer miał mniejszościowe udziały w kilkudziesięciu tytułach ${ }^{16}$, okazał się niewystarczająco zyskowny i koncern zakończył tam działalność. W Polsce, w ramach restrukturyzacji zasobów biznesowych, Bauer sprzedał na razie portal Interia.pl.

\section{Bibliografia}

Dąbrowska-Cendrowska O. (2009). Niemieckie koncerny prasowe w Polsce w latach 1989-2008. Warszawa: Elipsa.

Dąbrowska-Cendrowska O. (2019). Zagraniczni wydawcy polskiej prasy kobiecej i młodzieżowej. Zagrożenie dla polskich rodzin? „Zeszyty Prasoznawcze”, 62, 1(237), s. 80-96.

Diagnoza społecznych zachowań czytelniczych $w$ obrębie prasy papierowej i cyfrowej. Nowe platformy dostępu do treści. Transformacja prasy, http://www.pik.org.pl/upload/files/Raport\%20RYNEK\%2011-02-2014\%20(R)\%20word\%20IWP-2.pdf (dostęp: 14.09.2020).

Dziwisińska J. (2014). Kiedy zabraknie prasy, wywiad z Witoldem Woźniakiem, http://mediamarketingpolska.pl/artykuly/174807,kiedy-zabraknie-prasy (dostęp: 14.09.2020).

Gemius (2019). 20+, 40+, 60+ - Co wiemy o pokoleniach Polaków w sieci?, https://www.gemius.pl/wszystkie-artykuly-aktualnosci/id-20-40-60-co-wiemy-o-pokoleniach-polakow-w-sieci.html (dostęp: 14.09.2020).

IWP. Rynek prasy, https://iwp.pl/rynek-wydawcow/ (dostęp: 10.09.2020).

Jd (2018). Bauer tworzy platformę Influence Me do współpracy z twórcami internetowymi, https://www.wirtualnemedia.pl/artykul/bauer-influence-me-izabela-sarnecka-wspolpraca-z-influencerami (dostęp: 14.09.2020).

KRS. Sprawozdania finansowe Wydawnictwa Bauer.

Lista 500 „Rzeczpospolitej”, https://rankingi.rp.pl/firmy/grupa-kapitalowa-bauer-media (dostęp: 14.09.2020).

Niewiadomska J. (2019). Zachowując DNA marki. „Media \& Marketing Polska”, 10.

PBI (2016). Internetowe serwisy o zdrowiu, http://pbi.org.pl/wp-content/uploads/2016/11/03-RAPORT-Internetowe-serwisy-o-zdrowiu-2016.pdf (dostęp: 10.09.2020).

Prewęcka K. (1999). Bauer dla mas. „Media Polska”, 1.

Publicis Groupe (2020). Rynek reklamy w Polsce w I pótroczu 2020 roku, https://cmoinsider.pl/ (dostęp: 14.09.2020).

Raport Wydawnictwa Bauer (2020). Zmiana zachowań w świecie pełnym wyzwań. Jak zmienia się życie $w$ obliczu pandemii $i$ jakie ma to przełożenie na czytanie prasy, https://bauer.pl/ wp-content/uploads/2020/04/Mocna-pozycja-magazyn\%C3\%B3w-w-okresie-pandemii_ Raport-Wydawnictwa-Bauer.pdf (dostęp: 10.09.2020).

16 Ze względu na wprowadzone w końcu 2014 r. w Rosji przepisy zagraniczni wydawcy musieli zmniejszyć swoje udziały w tamtejszych mediach do $20 \%$. 
Reuters Institute (2019). Digital News Report 2019, https://reutersinstitute.politics.ox.ac.uk/sites/default/files/2019-06/DNR_2019_FINAL_0.pdf (dostęp: 10.09.2020).

Sokół Z. (2004). Wydawnictwo H. Bauer w Polsce w latach 1991-2002. Część I. „Rocznik Historii Prasy Polskiej", VII, 2(14), s. 113-143.

Sokół Z. (2005). Wydawnictwo H. Bauer w Polsce w latach 1991-2002. Część II, „Rocznik Historii Prasy Polskiej", VIII, 1(15), s. 124-143.

Tw (2020). Grupa ZPR Media rezygnuje z miesięcznika „Zdrowie” i zwalnia pracowników, https://www.wirtualnemedia.pl/artykul/koniec-miesiecznika-zdrowie-wlasciel-zpr-media-zwalnia-pracownikow (dostęp: 10.09.2020).

Wydawcy (2019). Dodatek do „Media \& Marketing Polska”, 5.

ZKDP [Związek Kontroli Dystrybucji Prasy]. Wyniki sprzedaży czasopism płatnych, https:// www.pbc.pl/wyniki-audytu/ (dostęp: 10.09.2020). 